\title{
Effects of an alternating work shift on air traffic controllers and the relationship with excessive daytime sleepiness and stress
}

\section{Efeitos do turno de trabalho alternado em controladores de tráfego aéreo e relação com sonolência diurna excessiva e estresse}

Ângela M. Freitas' ${ }^{1}$, Mirna Wetters Portuguez 1,2, Thaís Russomano ${ }^{3}$, Marcos de Freitas ${ }^{4}$, Silvio Luis da Silva Silvello ${ }^{4}$, Jaderson Costa da Costa ${ }^{1,2}$

\begin{abstract}
Objective: To evaluate symptoms of stress and excessive daytime sleepiness (EDS) in air traffic control (ATC) officers in Brazil. Methods: Fifty-two ATC officers participated, based at three air traffic control units, identified as A, B and C. Stress symptoms were assessed using the Lipp Inventory of Stress Symptoms for Adults, and EDS by the Epworth Sleepiness Scale. Results: The sample mean age was 37 years, $76.9 \%$ of whom were male. Excessive daytime sleepiness was identified in $25 \%$ of the ATC officers, with $84.6 \%$ of these based at air traffic control unit A, which has greater air traffic flow, operating a 24-hour alternating work shift schedule. A total of $16 \%$ of the ATC officers had stress symptoms, and of these, $62 \%$ showed a predominance of physical symptoms. Conclusion: The high percentage of ATC officers with EDS identified in group A may be related to chronodisruption due to night work and alternating shifts.
\end{abstract}

Keywords: disorders of excessive somnolence; workload; physiological stress; psychological stress

\section{RESUMO}

Objetivo: Avaliar sintomas de estresse e sonolência diurna excessiva (SDE) em controladores de tráfego aéreo (CTA) do Brasil. Métodos: Participaram 52 controladores pertencentes a 3 órgãos de controle de tráfego aéreo, denominados de A, B e C. Os sintomas de estresse, foram avaliados pelo Inventário de Sintomas de Estresse para Adultos, a SDE pela Escala de Sonolência Epworth. Resultados: 76,9\% da amostra são do sexo masculino, com média de idade de 37 anos. SDE foi identificada em 25\% dos controladores, desses 84,6\%, pertencem aos órgãos de controle de tráfego aéreo A, caracterizado por maior movimento de aeronaves, funcionamento 24 horas e escala de serviço em turnos alternantes. Um total de 16\% dos controladores apresentam sintomas de estresse, desses, 62\% mostraram o predomínio de sintomas físicos. Conclusão: A porcentagem elevada de CTA com SDE identificada no grupo A pode estar relacionada a cronodisrupção devido ao trabalho noturno e alternado.

Palavras-chave: distúrbios do sono por sonolência excessiva; carga de trabalho; estresse fisiológico; estresse psicológico.

Brazil is responsible for the administration of its territorial airspace $\left(8,511,965 \mathrm{~km}^{2}\right)$ and the airspace over the ocean. Numerous events, such as commercial and military flights, take place simultaneously in this vast area ${ }^{1}$. In this scenario, air traffic control (ATC) officers are the professionals fundamental to the success of thousands of takeoffs and landings, and are responsible for the control of civil and military aircraft, either in flight or on the ground, by means of radar and non-radar systems ${ }^{2}$.
The functions of ATC officers, according to the Department of Airspace Control, include: (a) identification of each aircraft in Brazilian airspace, in such a manner that no errors occur in pilot instructions; (b) awareness of the performance of each aircraft, knowledge of its route, flight altitude and speed, real-time location, positional changes and positioning in relation to other aircraft, and the correct use of communications media to control activity and air safety.

${ }_{1}^{1}$ Pontifícia Universidade do Rio Grande do Sul, Programa de Pós-Graduação em Medicina e Ciências da Saúde, Porto Alegre RS, Brasil;

${ }^{2}$ Pontifícia Universidade do Rio Grande do Sul, Instituto do Cérebro do Rio Grande do Sul, Porto Alegre RS, Brasil;

${ }^{3}$ King's College London, Centre of Human \& Aerospace Physiological Sciences, Graduate Program in Space Physiology \& Health, Faculty of Life Sciences and Medicine, London, England, UK;

«Empresa Brasileira de Infraestrutura Aeroportuária, Gestão Regional de Navegação Aérea, NASU/SRSU, Porto Alegre RS, Brasil.

Correspondence: Ângela Maria de Freitas; Instituto do Cérebro do Rio Grande do Sul - PUCRS; Avenida Ipiranga, 6690 / prédio 63, Jardim Botânico;

90610-000 Porto Seguro RS, Brasil; E-mail: mirna@pucrs.br

Conflict of interest: There is no conflict of interest to declare.

Received 26 September 2015; Received in final form 14 May 2017; Accepted 12 July 2017. 
The ATC officers' activities are divided into the areas of the airport control tower and the approach control center. The airport control tower is responsible for the aerodrome control service for ground-based aircraft maneuvering, and for the takeoff, landing and overflying the airfield phases. It seeks to avoid collisions with other aircraft, obstacles and vehicles moving on the ground. The approach control center is responsible for the approach control service for aircraft carrying out procedures for airport arrival or departure, aiming to ensure separation from other aircraft or obstacles ${ }^{3}$. The work of the ATC officers involves great mental and emotional loads, as the role requires high levels of cognitive tasks; it is they who make the decisions, sometimes in very limited time periods ${ }^{4}$. The consequences of this overload generate increased stress levels, alterations in cognitive performance (linked to attention and memory), and difficulties in maintaining good sleep quality. High stress levels in ATC officers can affect the performance of these professionals and can be the cause of boredom and decreased concentration ${ }^{5}$.

A further relevant factor is the performance of cognitive tasks that require the controllers to have an adaptive capacity due to the unpredictable environment in which they work ${ }^{6}$.

Evaluation of excessive daytime sleepiness (EDS) is indicated for professions that involve risk. Excessive daytime sleepiness is characterized by an inability to stay awake and alert during the main periods of daytime wakefulness, resulting in sleepiness and lapses of unintended sleep ${ }^{7}$, and can occur particularly when alternating shift work schedules are involved. Variations in shift work, including overnight or rotating shifts, can cause difficulties in sleeping that may lead to a circadian rhythm sleep disorder ${ }^{8}$. When the internal and external rhythmic signals are not in agreement with the biological clock, the circadian system experiences a misalignment, called interruption or desynchronization, which corresponds to an alteration of the circadian parameters ${ }^{9}$. This interruption, defined as a disturbance of the internal temporal order and of the physiological, biochemical and behavioral circadian rhythms is called chronodisruption ${ }^{10}$. In many workers subjected to shift work, this chronodisruption allows the development of a shift work disorder ${ }^{9}$. A shift work disorder is characterized by excessive sleepiness and/or sleep disturbances associated with the work schedule, although some night workers are able to adjust their circadian rhythm to night work ${ }^{11,12}$. Shift and/or night workers tend to have two to four hours less sleep, on a daily basis, which in the long run results in sleep deprivation.

The impact of EDS on the working adult manifests as decreased productivity, increased absenteeism, higher accident rates and a high probability of disability caused by an EDS-related disease ${ }^{13}$. The National Transportation Safety Board and National Air Traffic Controllers Association have recommended to the Federal Aviation Administration a revision of ATC officers' schedules in order to provide them with rest periods long enough to obtain sufficient restorative sleep ${ }^{14}$. This study aimed to correlate the symptoms of stress and EDS with the activity of air traffic control.

\section{METHODS}

\section{Sample}

The study included 52 ATC officers located at three different Brazilian airports, identified as groups A $(n=29)$, $B(n=12)$ and $C(n=11)$. In the airports involving groups $\mathrm{B}$ and $\mathrm{C}$, the work day was divided into three periods: from 06:00 h to 12:00 h; 12:01 h to 18:00 h; and 18:01 h to 23:59 h. Different teams operated in each of these periods and all air traffic control activities ceased at 24:00 h. The ATC officers at these airports had one day off for every three days worked. In the airport involving group A, an additional period was worked from 00:00 h to 06:00 h, completing a 24-hour total period of air traffic control activities. The ATC officers evaluated performed alternating shifts on each workday. The weekly workload hours (sequence of shifts worked consecutively) did not exceed a 36-hour limit. The rest periods between two shifts (consecutive days) and two sequences of shifts were no less than 11 hours and 35 hours, respectively.

The positive correlation $(0.300<\mathrm{r}<0.600)$ between stress and EDS was considered when determining the sample size of 52 ATC officers. A non-probabilistic convenience sampling, with sequential selection was adopted as the selection method.

This study was approved by the Scientific Commission of the Postgraduate Program and the Research Ethics Committee of PUCRS, on 21/11/2013, under number 462.813. Participants in this study did so voluntarily and signed an informed consent form.

\section{INSTRUMENTS}

Questionnaire applied to the ATC officers: Prepared specifically for this study in order to collect demographic and occupational data, and details of health conditions. The characteristics analyzed were gender, age, educational level, working hours, technical capability and place of work.

Lipp Inventory of Stress Symptoms for Adults (LISS): Aimed at youths and adults, and designed to measure overall symptoms of stress, not just occupational. Validated by Lipp and Guevara in São Paulo, 1994, it uses the sum total of physical and psychological symptoms as an indicator ${ }^{15}$.

Epworth Sleepiness Scale: Developed based on observations related to the nature and occurrence of daytime sleepiness. The aim of this instrument is to quantify the degree of sleepiness during eight routine activities and to identify sleep disorders. Test scores range from 0-24 points, with a score above 10 points suggesting a diagnosis of $\operatorname{EDS}^{16}$.

The Epworth Sleepiness Scale was chosen as it is validated for use in Brazil ${ }^{13}$. 


\section{RESULTS}

Analysis of the 13 professionals exhibiting EDS verified that $92.3 \%(\mathrm{n}=12)$ were male; $53.8 \%(\mathrm{n}=7)$ completed higher education; $61.5 \%(\mathrm{n}=8)$ performed the airport control tower/approach control center function; $46.2 \%(n=6)$ were aged 40 years or older; median length of work of 8.9 years (mean \pm SD of $9.6 \pm 6.4$ years); and $83.3 \%(n=10)$ reported undertaking physical activity (Table 1).

An absence of stress was predominant in the ATC officers operating in all three air traffic control units, together with the presence of low levels of EDS among the total sample, as shown in Table 2.

A comparison of sociodemographic variables with excessive daytime sleepiness and stress symptoms found no

Table 1. Sociodemographic distribution of air traffic control professionals in southern Brazil.

\begin{tabular}{|c|c|c|}
\hline \multirow{2}{*}{ Characteristics } & \multicolumn{2}{|c|}{ Sample total $(n=52)$} \\
\hline & $n$ & $\%$ \\
\hline \multicolumn{3}{|l|}{ Air Traffic Control Unit } \\
\hline A & 29 & 55.8 \\
\hline$B$ & 12 & 23.1 \\
\hline C & 11 & 21.2 \\
\hline \multicolumn{3}{|l|}{ Sociodemographic data } \\
\hline \multicolumn{3}{|l|}{ Gender } \\
\hline Female & 12 & 23.1 \\
\hline Male & 40 & 76.9 \\
\hline \multicolumn{3}{|l|}{ Age } \\
\hline Mean ( \pm SD) (Range) yr. & \multicolumn{2}{|c|}{$37.9( \pm 8.5)(24-61)$} \\
\hline \multicolumn{3}{|l|}{ Age group } \\
\hline Up to $39 \mathrm{yr}$. & 30 & 57.7 \\
\hline $40+$ yr. & 22 & 42.3 \\
\hline \multicolumn{3}{|l|}{ Educational level } \\
\hline HSC & 2 & 3.8 \\
\hline $\mathrm{HEl}$ & 14 & 26.9 \\
\hline HEC & 32 & 61.5 \\
\hline Postgraduate & 4 & 7.7 \\
\hline \multicolumn{3}{|l|}{ Time working (years) } \\
\hline Mean ( \pm SD) (Median) & 12.1 & 12.0) \\
\hline \multicolumn{3}{|c|}{ Time working in present activity* } \\
\hline Less than 2 years & 8 & 16.0 \\
\hline From 2 to 6 years & 12 & 24.0 \\
\hline More than 6 years & 30 & 60.0 \\
\hline \multicolumn{3}{|l|}{ Technical qualifications } \\
\hline TWR & 24 & 46.2 \\
\hline APP & 1 & 1.9 \\
\hline TWR and APP & 27 & 51.9 \\
\hline \multicolumn{3}{|l|}{ Health data } \\
\hline \multicolumn{3}{|l|}{ Physical activity* } \\
\hline Yes & 37 & 74.0 \\
\hline No & 13 & 26.0 \\
\hline \multicolumn{3}{|l|}{ Chronic disease* } \\
\hline Yes & 9 & 18.0 \\
\hline No & 41 & 82.0 \\
\hline
\end{tabular}

statistical association. However, data analysis revealed a statistically significant association between location of work and the sleepiness scale results (Fisher's exact test by Monte Carlo simulation, $\mathrm{p}<0.05$ ).

According to the Epworth Sleepiness Scale, 25\% ( $n=13)$ of the total number of ATC officers presented with scores indicating EDS and, of this number, 84.6\% $(n=11)$ belonged to the Air Traffic Control Unit A, suggesting a possible relationship between sleepiness and the 24-hour work pattern of that particular unit (Table 2).

Considering only those ATC officers working between 00:00 $\mathrm{h}$ and 6:00 $\mathrm{h}(\mathrm{n}=29)$, just 38\% (11) presented with excessive daytime sleepiness, with the remainder (62\%) being unaffected. In relation to the obtained LISS test scores, $84 \%$ exhibited no stress, and only $13.8 \%$ of the ATC officers based at Air Traffic Control Unit A presented with LISS scores equating to stress.

Comparing the ATC officers' employment duration, significant differences were identified in relation to EDS (excessive sleepiness: $9.3 \pm 9.6$; median: 4.0 vs. no excessive sleepiness $12.6 \pm 9.7$; median: $13.0 ; \mathrm{p}=0.027$ ) and stress (with stress: $9.5 \pm 8.5$; median: 12.0 vs. no stress $12.0 \pm 9.9$; median: 11.0 ; $\mathrm{p}=0.047$ ). (Mann-Whitney test, $\mathrm{p}>0.05)$ (Figure 1).

\section{DISCUSSION}

The direct implications of EDS and stress symptoms in air traffic control are still not well defined. There are few studies in Brazil regarding the effects of EDS and stress on ATC officers.

These findings are in agreement with other research involving military ATC officers in the state of Pernambuco, which, using the Epworth Sleepiness Scale, identified excessive sleepiness in $66.7 \%(\mathrm{n}=30)$ of the 45 flight protection professionals ${ }^{17}$.

Comparative analysis between EDS and the air traffic control units (Table 3 ) revealed that $84.6 \%(\mathrm{n}=11)$ of the ATC officers with EDS were located in Air Traffic Control Unit A,

Table 2. Absolute and relative distribution of stress and sleep classifications - LISS and ESS

\begin{tabular}{lcc}
\hline \multirow{2}{*}{ Variables } & \multicolumn{2}{c}{ Sample total $(\mathrm{n}=52)$} \\
\cline { 2 - 3 } & $\mathrm{n}$ & $\%$ * \\
\hline $\begin{array}{l}\text { (LISS)- Stress } \\
\quad \text { No stress }\end{array}$ & 42 & 84.0 \\
$\quad$ With stress & 8 & 16.0 \\
\hline $\begin{array}{l}\text { Physical and/or psychological stress } \\
\quad \text { Physical symptoms }\end{array}$ & 5 & 62.5 \\
\hline $\begin{array}{l}\text { Psychological symptoms } \\
\text { (ESS) Sleepiness evaluation }\end{array}$ & 3 & 37.5 \\
$\quad \begin{array}{l}\text { Up to 10 points non-excessive } \\
\text { sleepiness - NORMAL }\end{array}$ & 39 & 75.0 \\
$\quad$ Above 10 points excessive sleepiness & 13 & 25.0 \\
\hline
\end{tabular}

LISS: Lipp inventory of stress symptoms for adults; ESS: Epworth sleepiness scale. *Percentages obtained based on total number of valid cases; $* \star 3.8 \%$ ( $n=2)$ of data missing. 

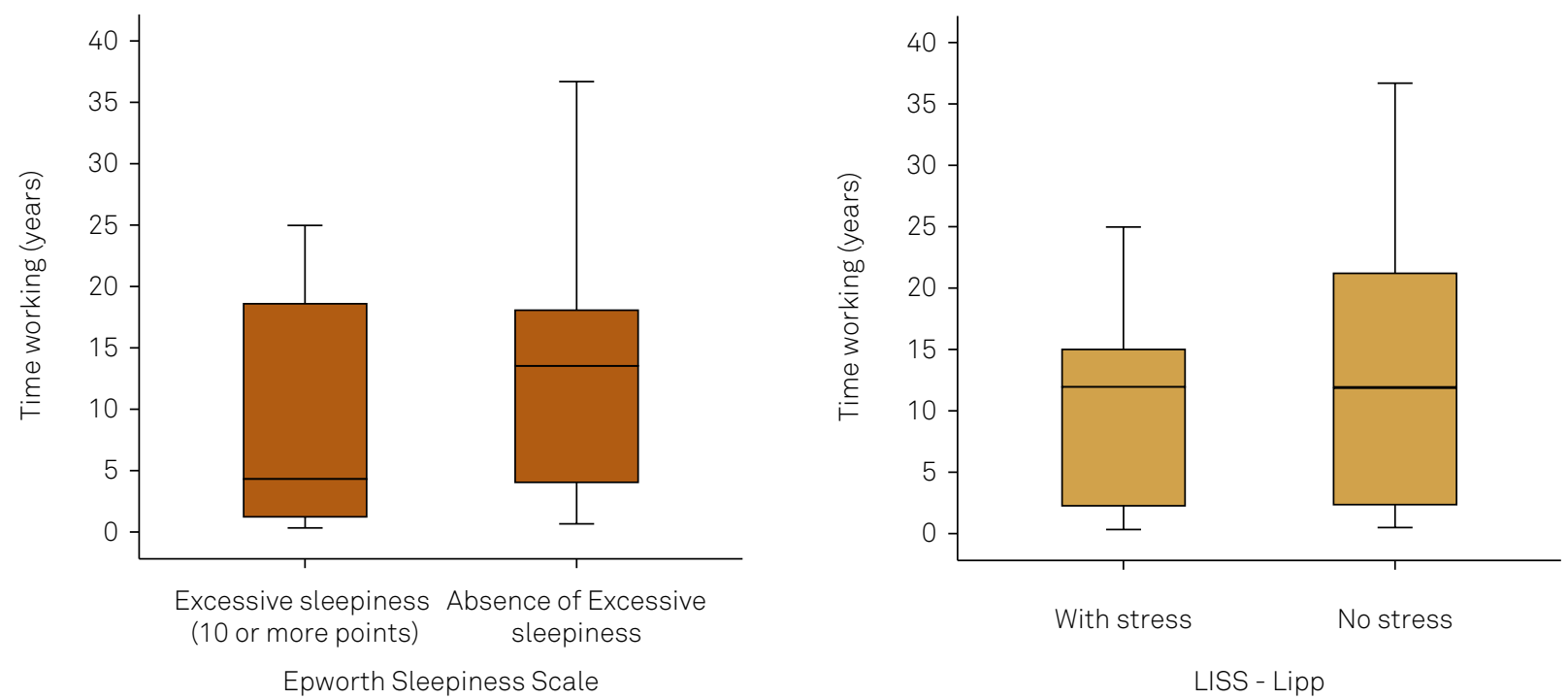

Figure. Boxplot of air traffic control activity employment duration according to stress and sleepiness test results.

which operates 24 hours a day with a four-shift schedule, and has a greater flow of aircraft.

The relationship between sleepiness and place of work is not sufficient to fully explain the presence of EDS, as other factors should also be considered. It is also important to emphasize that the results related to the sociodemographic, professional and health characteristics of the 52-strong sample of professionals identified no statistical significance between the three places of work.

Approximately $20 \%$ of the working population in industrialized countries is engaged in shift and/or night work. This type of employment, therefore, exposes a large number of workers to unusual light-dark cycles ${ }^{9}$, as is the case with shift and night work ${ }^{18,19}$.

Exposure to artificial light at night results in a disruption of the circadian system, which is deleterious to health. The potential and multifactorial mechanisms of the effects include the suppression of melatonin secretion by artificial light at night, sleep deprivation and circadian disruption. Shift and/or night work generally decreases the time spent sleeping, and disrupts the circadian time structure9. Desynchronization manifests itself through atypical clinical symptoms, such as persistent fatigue, sleep disorders leading to chronic insomnia, poor appetite, and mood disorders that can cause depression, although some desynchronized individuals do not experience any of these clinical signs ${ }^{12}$. These effects are thought to be linked to a loss of synchronization between the internal clock and the lightdark cycle ${ }^{9}$. Many shift workers who have a misaligned circadian rhythm due to working nights are at higher risk of developing shift work disorder. Therefore, a possible explanation for the higher percentage of EDS in group A in this study may be due to chronodisruption caused by the ATC officers working nights.
This result highlights the importance of changes in the circadian rhythm of the ATC officers. Even with consecutive days off and sufficient rest time, alternating work shift patterns affect the circadian rhythm and state of alertness as a consequence, which has been confirmed in studies such as that by Belyavin and Spencer ${ }^{20}$. The importance of circadian rhythm and homeostasis in alertness levels and the decisionmaking process in ATC officers in Brazil has also been demonstrated in research by Franco Noce ${ }^{21}$.

Although not statistically significant, the number of ATC officers with EDS becomes relevant from a clinical and occupational viewpoint due to the complexity and risk inherent in the performed activity. No statistically significant associations were found following comparative analysis of the EDS classification in relation to gender, age, age group, educational level, physical activity, perception of physical and psychological health, job function and working time. However, some factors contributing to the continuity of EDS have external causes, such as sleep deprivation, rotational shift work, poor sleep hygiene, and sleep disturbances related to the consumption of caffeinated drinks ${ }^{22}$, factors also encountered in the present cohort. Some researchers report that shift worker sleepiness can occur due to an insufficient amount of total sleep time or greater sleep fragmentation ${ }^{23}$. Excessive daytime sleepiness has also been linked to traffic accidents; the proportion of accidents attributed to EDS in the United States ranges from 1-3\%, while in Australia this figure can reach $33 \%$ of registered incidents ${ }^{24}$. In relation to stress, the present study observed that only $16 \%$ of the ATC officers presented with symptoms of stress, with $62 \%(n=5)$ of these showing a predominance of physical symptoms (Table 2). A review of research focusing on stress in Brazilian ATC officers found high rates of association with the presence of stress. Records of aircraft accidents involving ATC officers can be found in 
Table 3. Sociodemographic and health characteristics of ATC officers in southern Brazil according to ESS and LISS results.

\begin{tabular}{|c|c|c|c|c|c|c|c|c|c|c|}
\hline \multirow{4}{*}{ Variables } & \multicolumn{10}{|c|}{ Sample Total $(n=52) *$} \\
\hline & \multicolumn{5}{|c|}{ Epworth Sleepiness Scale (ESS) } & \multicolumn{5}{|c|}{ Stress Symptoms (LISS) } \\
\hline & \multicolumn{2}{|c|}{$\begin{array}{l}\text { Excessive } \\
\text { sleepiness } \\
(n=13)\end{array}$} & \multicolumn{2}{|c|}{$\begin{array}{c}\text { Absence of } \\
\text { sleepiness } \\
(n=39)\end{array}$} & \multirow[t]{2}{*}{$\mathrm{p}$} & \multicolumn{2}{|c|}{$\begin{array}{l}\text { Presence } \\
\text { of stress } \\
(n=8)\end{array}$} & \multicolumn{2}{|c|}{$\begin{array}{l}\text { Absence } \\
\text { of stress } \\
(n=42)\end{array}$} & \multirow[t]{2}{*}{$\mathrm{p}$} \\
\hline & $\mathrm{n}$ & $\%$ & $\mathrm{~N}$ & $\%$ & & $\mathrm{n}$ & $\%$ & $\mathrm{n}$ & $\%$ & \\
\hline \multicolumn{11}{|l|}{ Sociodemographic data } \\
\hline \multicolumn{11}{|l|}{ Gender } \\
\hline Female & 1 & 7.7 & 11 & 28.2 & \multirow{2}{*}{$0.253 \pi$} & 2 & 25.0 & 10 & 22.7 & \multirow{2}{*}{$>0.999$} \\
\hline Male & 12 & 92.3 & 28 & 71.8 & & 6 & 75.0 & 34 & 77.3 & \\
\hline \multicolumn{11}{|l|}{ Age (years) } \\
\hline Mean $\pm S D$ & \multicolumn{2}{|c|}{$37.8 \pm 7.8$} & \multicolumn{2}{|c|}{$37.9 \pm 8.9$} & $0.971 €$ & \multicolumn{2}{|c|}{$37.9 \pm 8.1$} & \multicolumn{2}{|c|}{$37.9 \pm 8.7$} & $0.822 €$ \\
\hline \multicolumn{11}{|l|}{ Age group } \\
\hline Up to $39 \mathrm{yr}$. & 7 & 53.8 & 23 & 59.0 & \multirow{2}{*}{$>0.999 \pi$} & 3 & 37.5 & 27 & 61.4 & \multirow{2}{*}{$0.160 \pi$} \\
\hline $40+y r$ & 6 & 46.2 & 16 & 41.0 & & 5 & 62.5 & 17 & 38.6 & \\
\hline Educational level & & & & & & & & & & \\
\hline HSC & 1 & 7.7 & 1 & 2.6 & & & & 2 & 4.5 & \\
\hline $\mathrm{HEl}$ & 4 & 30.8 & 10 & 25.6 & 7 70 & 2 & 25.0 & 12 & 27.3 & $0500 \pi$ \\
\hline HEC & 7 & 53.8 & 25 & 64.1 & 0.18411 & 5 & 62.5 & 27 & 61.4 & 0.59011 \\
\hline Postgraduate & 1 & 7.7 & 3 & 7.7 & & 1 & 12.5 & 3 & 6.8 & \\
\hline Professional data & & & & & & & & & & \\
\hline Air Traffic Control Unit & & & & & & & & & & \\
\hline A & 11 & 84.6 & 18 & 46.2 & & 4 & 50.0 & 25 & 56.8 & \\
\hline $\mathrm{B}$ & 1 & 7.7 & 11 & 28.2 & $0.045 \pi$ & 2 & 25.0 & 10 & 22.7 & $0.956 \pi$ \\
\hline C & 1 & 7.7 & 10 & 25.6 & & 2 & 25.0 & 9 & 20.5 & \\
\hline Time working (years) & & & & & & & & & & \\
\hline Mean \pm SD (Median) & $9.3=$ & $(12.0)$ & 12.8 & (13.5) & $0.274 ¥$ & 10.5 & (12.0) & 12.3 & (12.0) & $0.322 ¥$ \\
\hline Time working in preser & tivity & & & & & & & & & \\
\hline Less than 2 years & 5 & 38.5 & 5 & 12.8 & & 2 & 25.0 & 8 & 18.2 & \\
\hline From 2 to 6 years & 3 & 23.1 & 9 & 23.1 & $0.155 \pi$ & 1 & 12.5 & 11 & 25.0 & $0.769 \pi$ \\
\hline More than 6 years & 5 & 38.5 & 25 & 64.1 & & 5 & 62.5 & 25 & 56.8 & \\
\hline Technical qualification & & & & & & & & & & \\
\hline TWR & 5 & 38.5 & 19 & 48.7 & & 5 & 62.5 & 19 & 43.2 & \\
\hline APP & & & 1 & 2.6 & $0.654 \pi$ & & & 1 & 2.3 & $0.539 \pi$ \\
\hline TWR and APP & 8 & 61.5 & 19 & 48.7 & & 3 & 37.5 & 24 & 54.5 & \\
\hline Health data & & & & & & & & & & \\
\hline Physical activity** & & & & & & & & & & \\
\hline Yes & 10 & 83.3 & 27 & 71.1 & & 5 & 62.5 & 32 & 76.2 & \\
\hline No & 2 & 16.7 & 11 & 28.9 & 0.4809 & 3 & 37.5 & 10 & 23.8 & 0.4139 \\
\hline Chronic disease ${ }^{\star \star}$ & & & & & & & & & & \\
\hline Yes & 3 & 25.0 & 6 & 15.8 & ० 668 & 3 & 37.5 & 6 & 14.3 & $0144 \pi$ \\
\hline No & 9 & 75.0 & 32 & 84.2 & U.6081 & 5 & 62.5 & 36 & 85.7 & 0.14411 \\
\hline Medication use ${ }^{\star \star}$ & & & & & & & & & & \\
\hline Yes & 2 & 16.7 & 6 & 15.8 & & 1 & 12.5 & 7 & 16.7 & م 990 \\
\hline No & 10 & 83.3 & 32 & 84.2 & $>0.999 \|$ & 7 & 87.5 & 35 & 83.3 & $>0.999 \|$ \\
\hline
\end{tabular}

HSC: high school complete; HEl: higher education incomplete; HEC: higher education complete; TWR: airport control tower; APP: approach control center *Percentage obtained based on the total for sleepiness or stress test categories; ¥: Mann Whitney test; $\mathbb{\uparrow}$ : Fisher’s Exact Test; $€$ : Student $t$ test for independent groups; SD: standard deviation. **3.8\% $(n=2)$ of data missing.

annual Department of Airspace Control reports produced in Brazil (ICA 63-16, 2013; ICA 63-16, 2014). The variable of psychological stress was reported in only $3.98 \%$ and $4.2 \%$ of cases in 2012 and 2013, respectively ${ }^{25,26}$. These findings are in agreement with research that analyzed the perception of stress in four distinct occupational categories: air traffic controllers, operators within a radioactive environment, professors and doctors. The results indicated that even though the role of an ATC officer is extremely stressful, the lowest level of stress occurred in this group, demonstrating more active and efficient stress coping methods in comparison to the other occupations ${ }^{27}$. A research report from 2012 conducted by the National Aeronautics and Space Administration (NASA), commissioned by the United States Federal Aviation Administration, revealed that ATC officers' work schedules often lead to chronic fatigue, making controllers less alert 
and endangering the safety of the national air traffic system ${ }^{28}$. The NASA researchers conducted a survey of 3,268 ATC officers regarding their work schedules and sleep habits, and also performed a field study monitoring 200 controllers at 30 air traffic facilities through the use of wrist actigraphy sensors and psychomotor vigilance tests measuring timed reactions. The report appears to confirm the results obtained in the present study: occupational components and sleep conditions are seen to be decisive for an ATC officer's activity since these variables have a direct effect on the ATC officer's performance. It should be pointed out that the Federal Aviation Administration did not accept the report findings, considering that the academic approach used by NASA did not sufficiently integrate an understanding of the 24/7 air traffic operational environment ${ }^{14}$. However, the report release came after a series of incidents involving controllers falling asleep on duty; for example, in 2011, two airliners landed at Washington's Reagan National Airport late at night without assistance from the airport control tower as the lone controller on duty had fallen asleep. The NASA report does highlight the importance of evaluating both EDS and the work environment of ATC officers, providing an understanding of important characteristics about professionals who operate in complex and high-responsibility systems ${ }^{14}$. Our findings showed the ATC officers affected by excessive daytime sleepiness belonged to group A, the only group involving night work, performing rotating night shifts interspersed with day shifts, in contrast to groups $\mathrm{B}$ and $\mathrm{C}$ who worked during the day only. According to the Federal Aviation Administration, this routine should be avoided in the work schedules (programming) of ATC officers and established as standard practice in air traffic control units, thus preventing the occurrence of incidents and accidents ${ }^{14}$. The small sample size and absence of previous studies involving ATC officers from the investigated region are identified as limitations of this research, making comparisons difficult. An additional limiting factor is the small number of airports that participated in the research.

\section{ACKNOWLEDGMENTS}

Special thanks to the Brain Institute, PUCRS, for their continued support in the development of this research.

\section{References}

1. Ministério da Defesa (BR). Departamento de Controle do Espaço Aéreo - DECEA. Gerenciamento do tráfego aéreo. Rio de Janeiro: DECEA; 2015 [cited 2015 Jun16]. Available from: http://www.decea. gov.br/espaco-aereo/gerenciamento-de-trafego-aereo/

2. Ministério da Educação (BR). Secretaria de Educação Profissional e Tecnológica. Eixo tecnológico militar. Brasilia, DF: Ministério da Educação; 2015 [acesso em 2015 Jun 16]. Available from: http:// pronatec.mec.gov.br/cnct/et_militar/t_contr_trafego_aereo.php

3. Perrow C. Normal accidents: living with high-risk Technologies. 2nd ed. New York: Princeton University Press; 2011.

4. Moreira SB, Vidal MC. Relatórios de pesquisas ergonômicas realizadas no controle de tráfego aéreo. Rio de Janeiro: Centro de Controle de Aproximação; 1999.

5. Loura J. Human factors and stress in air traffic controllers: a study of air traffic controllers at I.G.I Airport, New Delhi. Int J Trends Bus Admin. 2013;2(7):189-210.

6. Lapolli FR, Motta CL, Gomes JO, Tola CE. Lapolli FR LC, Motta R. Metacognição como processo de aprendizagem visando a construção de respostas adaptativas em profissionais que atuam em sistemas complexos. In: Proceedings of 2009 Brazilian Symposium on Aerospace Engineering and Applications, 3rd CTA-DLR Workshop on Data Analysis and Flight Control 2009 Sep 14-16, São José dos Campos, Brazil. São José dos Campos: CTA; 2009.

7. Stores G. Clinical diagnosis and misdiagnosis of sleep disorders. J Neurol Neurosurg Psychiatry. 2007;78(12):1293-7. https://doi.org/10.1136/jnnp.2006.111179

8. Drake CL, Roehrs T, Richardson G, Walsh JK, Roth T. Shift work sleep disorder: prevalence and consequences beyond that of symptomatic day workers. Sleep. 2004;27(8):1453-62. https://doi.org/10.1093/sleep/27.8.1453

9. Touitou Y, Reinberg A, Touitou D. Association between light at night, melatonin secretion, sleep deprivation, and the internal clock: health impacts and mechanisms of circadian disruption. Life Sci. 2017;173:94-106. https://doi.org/10.1016/j.lfs.2017.02.008
10. Erren TC, Reiter RJ, Reiter J.. Defining chronodisruption. J Pineal Res. 2009;46(3):245-7. https://doi.org/10.1111/j.1600-079X.2009.00665.x

11. Ashkenazi IE, Reinberg AE, Motohashi Y. Interindividual differences in the flexibility of human temporal organization: pertinence to jet lag and shiftwork, Chronobiol Int. 1997;14(2):99-113. https://doi.org/10.3109/07420529709001148

12. Reinberg A, Ashkenazi I. Internal desynchronization of circadian rhythms and tolerance to shift work. Chronobiol Int. 2008;25(4):625-43. https://doi.org/10.1080/07420520802256101

13. Bertolazi AN, Fagondes SC, Hoff LS, Pedro VD, Menna Barreto SS, Johns MW. Portuguese-language version of the Epworth sleepiness scale: validation for use in Brazil. J Bras Pneumol. 2009;35(9): 877-83. https://doi.org/10.1590/S1806-37132009000900009

14. U.S. Department of Transportation. Federal Aviation Administration. Washington, DC: Federal Aviation Administration; 2015 [cited 2015 Aug 21]. Available from: https://www.faa.gov/search/?q=Air+Traffic+ Controllers+and + Sleep +2015

15. Lipp ME. Manual do Inventário de sintomas de stress para Adultos de Lipp (ISSL). São Paulo: Casa do Psicólogo; 2000. p. 23-7.

16. Johns MW. Sensitivity and specificity of the multiple sleep latency test (MSLT), the maintenance of wakefulness test and the epworth sleepiness scale: failure of the MSLT as a gold standard.J Sleep Res. 2000;9(1):5-11.

17. Ribas V, Almeida CA, Martins $\mathrm{H}$, Alves CF, Alves MJ, Carneiro SM et al. Brazilian air traffic controllers exhibit excessive sleepiness. Dement Neuropsychol. 2011;5(3):209-15. https://doi.org/10.1590/S1980-57642011DN05030009

18. Reinberg A, Touitou Y. [Synchronization and dyschronism of human circadian rhythms]. Pathol Biol (Paris). 1996;44(6):487-95. French.

19. Reinberg A, Smolensky MH, Riedel M, Touitou Y, Le Floc'h N, Clarisse R et al. Chronobiologic perspectives of black time: accident risk is greatest at night: an opinion paper. Chronobiol Int. 2015;32(7):1005-18. 
20. Belyavin AJ, Spencer Mb. Modeling performance and alertness: the QinetiQ approach. Aviat Space Environ Med. 2004;75(3 Suppl):A93-103.

21. Noce F.A influência dos turnos de trabalho na tomada de decisão dos militares controladores do tráfego aéreo [thesis]. São Paulo: UNIFESP; 2010.

22. McWhirter D, Bae C, Budur K. The assessment, diagnosis, and treatment of excessive sleepiness: practical considerations for the psychiatrist. Psychiatry (Edgmont). 2007;4(9):26-35.

23. Monk TH, Folkard S, Wedderburn Al. Maintaining safety and high performance on shiftwork. Appl Ergon. 1996;27(1):17-23. https://doi.org/10.1016/0003-6870(95)00048-8

24. Connor J, Norton R, Ameratunga S, Robinson E, Civil I, Dunn R et al. Driver sleepiness and risk of serious injury to car occupants: population based case control study. BMJ. 2002;324(7346):1125. https://doi.org/10.1136/bmj.324.7346.1125
25. Ministério da Defesa (BR). Departamento de Controle do Espaço Aéreo - DECEA. ICA- 63-16. Programa de prevenção de acidentes aeronáuticos do departamento de controle do espaço aéreo. Brasília, DF: Ministério da Defesa; 2013. p. 18-9.

26. Ministério da Defesa (BR). Departamento de Controle do Espaço Aéreo - DECEA. ICA-63-16. Programa de prevenção de acidentes aeronáuticos do departamento de controle do espaço aéreo. Brasília, DF: Ministério da Defesa; 2014. p. 19-20.

27. Maier R. Dimensions of stress among air traffic controllers.J Psychol Educ Res. 2011;19(1):52-62.

28. U.S. Department of Transportation. Federal Aviation Administration. Título do documento visualizado. Washington, DC: Federal Aviation Administration; 2015 [cited 2015 Aug 10]. Available from: https://www.faa.gov/news/press_releases/news_ story.cfm?newsld=19294 